\title{
EXPERIMENTAL INVESTIGATION OF TECHNICAL AND OPERATIONAL INDICES OF ASYMMETRIC SWATH REAPER MACHINE-AND-TRACTOR AGGREGATE
}

\author{
Volodymyr Bulgakov $^{1}$, Valerii Adamchuk ${ }^{2}$, Semjons Ivanovs ${ }^{3}$, Hryhorij Kaletnik ${ }^{4}$ \\ ${ }^{1}$ National University of Life and Environmental Sciences of Ukraine, Ukraine; \\ ${ }^{2}$ National Scientific Centre "Institute for Agricultural Engineering and Electrification" of Ukraine, \\ Ukraine; ${ }^{3}$ Latvia University of Life Sciences and Technologies, Latvia; \\ ${ }^{4}$ Vinnytsia National Agrarian University, Ukraine \\ semjons@apollo.lv
}

\begin{abstract}
Asymmetric machine-and-tractor aggregates are often used for two-phase harvesting of cereals, when, at first, the cereals are in the phase of wax ripeness and they are mown into swaths, and then, as the mass dries out, reaching full maturity, they are threshed by combine harvesters. Such a method of harvesting cereals is very efficient in case the crops are wet and with an insufficiently even degree of maturity. A specificity of such trailed units is the presence of asymmetric tractive load upon the tractor, which causes unstable dynamics of the movement in a horizontal plane, a need to correct the direction of the movement, etc. The purpose of the investigation - to determine the optimal technical and operational indices of an asymmetric swath reaper machine-and-tractor aggregate according to the results of its field experimental research. Better quality of the operation of an improved swath reaper is ensured by the devices for setting its supporting wheels at an angle of $8^{\circ}$ to the direction of its movement. When using a more improved swath reaper, in contrast to the base variant, the productivity of the main time increases from $4.1 \mathrm{ha} \cdot \mathrm{h}^{-1}$ to $4.34 \mathrm{ha} \cdot \mathrm{h}^{-1}$, the specific fuel consumption - from $2.85 \mathrm{~kg} \cdot \mathrm{ha}^{-1}$ to $2.65 \mathrm{~kg} \cdot \mathrm{ha}^{-1}$, and the total loss of the loose grains and the grains in the cut ear - from $1.3 \%$ to $0.2 \%$.
\end{abstract}

Keywords: asymmetric, reaper, aggregate, productivity, losses, grain.

\section{Introduction}

Asymmetric machine-and-tractor aggregates are often used for harvesting cereals and grass [1-2]. Especially widely used in Ukraine are asymmetric swathe reaper aggregates for two-phase harvesting of cereals, when, at first, the cereals are in the phase of wax ripeness and they are mown into swaths, and then, as the mass dries out, reaching full maturity, they are threshed by combine harvesters. Such a method of harvesting cereals is very efficient in case the crops are wet and with an insufficiently even degree of maturity [3].

A specificity of such trailed units is the presence of asymmetric tractive load upon the tractor [4;5]. This causes unstable dynamics of the movement in a horizontal plane, a need to correct the direction of the movement, etc., which affects the operational and technological indicators of the aggregate as a whole [3;5]. To follow to the path of the movement of the machine-and-tractor aggregate, it is necessary to install the guiding (driving) wheels of the tractor at a certain angle to the longitudinal axis of symmetry of the tractor and to correct their direction constantly; the movement takes place at a certain speed.

The operation of asymmetric machine-and-tractor aggregates has been investigated by many scientists [4-7], the designs of the trailed machines that improve stability of the movement are being constantly improved. However, there are practically few studies of the impact of the design parameters upon the quality of work of the grain harvesters. For instance, there are an insufficient number of investigations of the impact of the speed conditions or certain improvement upon such technological and agrotechnical indicators as the losses of grain, the stubble cutting height, the width of the swathe, etc. Asymmetrical swath reapers ZVP-6 are widely used in Ukraine; in Western European countries Stoll R1405S, Krone Swadro TC930 V1.1.0.0, Agromet Famarol Z211 and others are used.

The purpose of the investigation - to determine the optimal technical and operational indices of an asymmetric swath reaper machine-and-tractor aggregate (MTA) according to the results of its field experimental research.

\section{Materials and methods}

The program of experimental investigation provided for the study of the impact of the speed of the movement of the harvesting aggregate upon the quality indicators of the cut stalk density of cereals 
and the parameters of the swath to be formed [8-12]. In particular, the object of research was a trailed swath reaper aggregate with a device for turning its supporting wheels.

The experimental investigations were conducted at four speeds $-1.8 ; 2.1 ; 2.8$ and $3.8 \mathrm{~m} \cdot \mathrm{s}^{-1}$, which correspond to the range of the operating speed of the swath reapers. The exact speed of the movement was controlled using a track measuring wheel.

In this case as the quality indicators of the cut stalk density the average height of the stubble and the coefficient of its variation, as well as the losses of grain were assumed. The average height of the stubble was determined by measuring it at five reference points by means of a tape measure with an accuracy of $\pm 1 \mathrm{~mm}$ after the passage of the harvesting unit, followed by the determination of the arithmetic average value and coefficient of variation according to generally accepted expressions. The grain losses were determined by overlaying a frame of $1 \mathrm{~m}^{2}$ at five points after the passage of the harvesting aggregate, collecting the loose grains and the grains in the ear, and then weighing them on electronic scales with an accuracy of $\pm 0.001 \mathrm{~g}$.

When conducting the experimental field investigations, as the main parameters of the swath were selected its width and thickness, measured in five test points according to existing methods by means of a tape measure with an accuracy of $\pm 1 \mathrm{~mm}$.

The research results were processed by the methods of mathematical statistics $[13 ; 14]$ and by constructing graphical and functional dependencies using the PC for PC Excel and Statistic. To estimate the fluctuations of the measured parameters, the standard deviation $\sigma$ was calculated (further indicated in the explanatory notes to the graphs).

In order to determine the operational and technological indicators of the asymmetric machineand-tractor aggregate, we carried out experimental investigations. For this purpose an aggregate was prepared, consisting of an MTZ-82 aggregating tractor and a trailed swath reaper (Fig. 1). Thus, on the basis of the swath reaping machine-and-tractor aggregate an experimental installation was created, which made it possible to obtain the performance indicators under real field conditions.

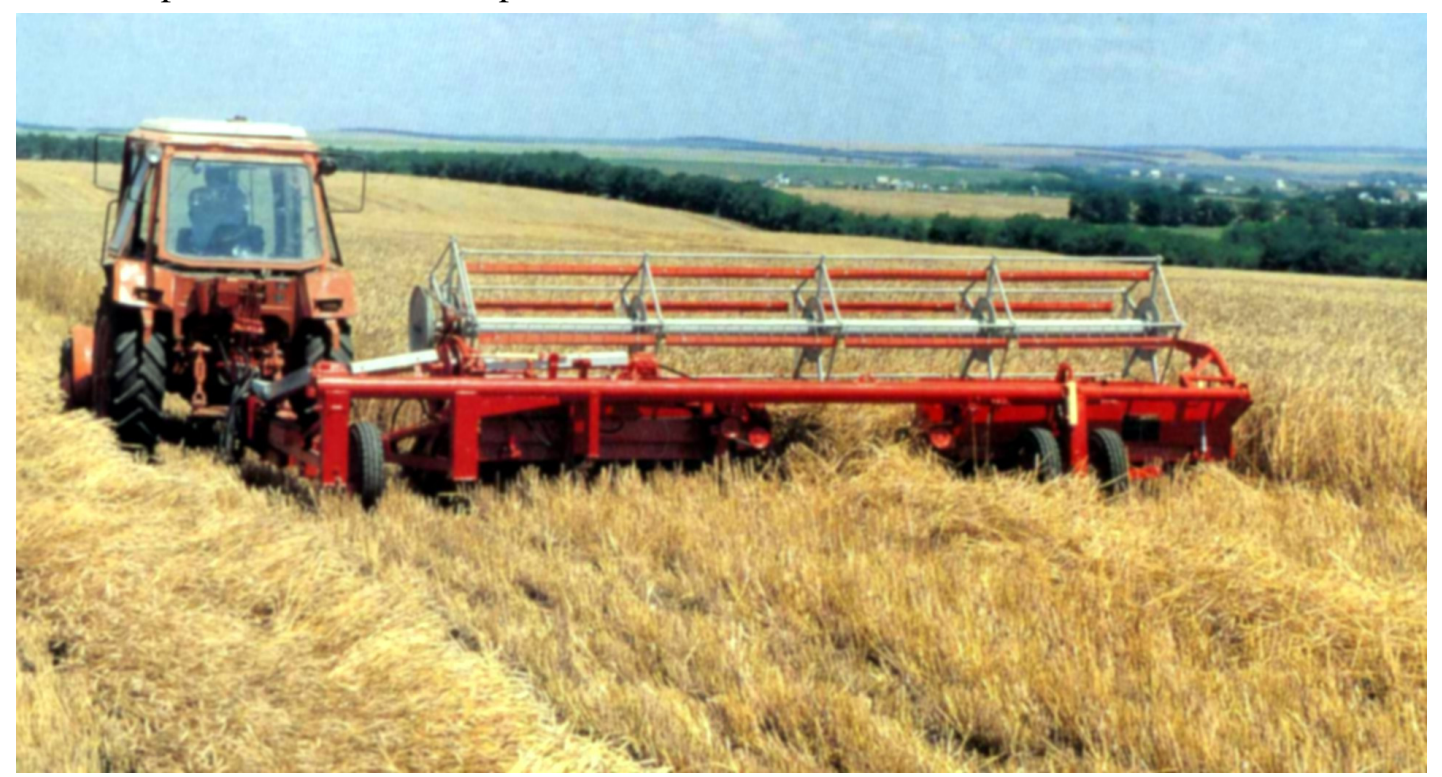

Fig. 1. Asymmetric swath reaper aggregate, prepared for experimental field investigations

During the experimental field investigations of this asymmetrical swath reaping machine-andtractor aggregate for a pre-calculated number of repetitions of experiments, accurate measurements of the performance indicators of this aggregate were made. A track-measuring wheel was installed on the swath reaper, which allowed to determine the actual speed of the movement and the path travelled by the aggregate with a sufficient degree of accuracy when conducting the field experimental studies (Fig. 2). In order to measure the forces that create the unwinding moment on the asymmetrically trailed swath reaper, a DEF-A2t strain gauge was used, the readings of which were recorded and processed using a special program on the PC (Fig. 3). 


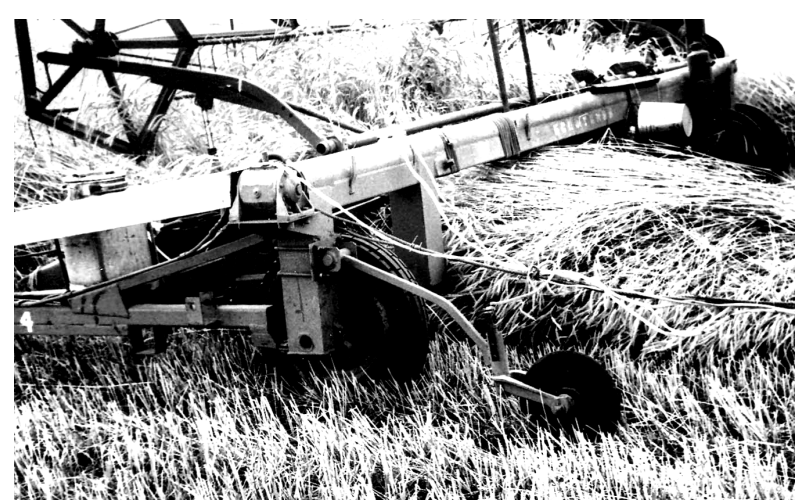

Fig. 2. Track-measuring wheel, installed on trailed swath reaper

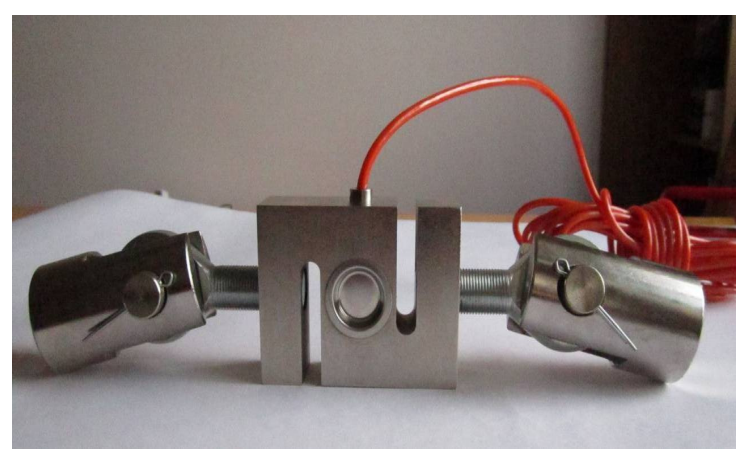

Fig. 3. Strain gauge DEF-A2t

The experimental investigations were performed on an agricultural background (agrofone), the characteristics of which are given in Table 1.

\section{Characteristics of the agrophone during the experimental investigations}

Table 1

\begin{tabular}{|l|c|}
\hline \multicolumn{1}{|c|}{ Indicator } & Value \\
\hline Soil moisture (\%) in the layer: & \\
$0 \ldots . .5 \mathrm{~cm}$ & 9.7 \\
$5 \ldots 10 \mathrm{~cm}$ & 12.4 \\
$10 \ldots 15 \mathrm{~cm}$ & 14.8 \\
\hline Soil hardness in the layer $0 \ldots 15 \mathrm{~cm}, \mathrm{MPa}$ & 2.3 \\
\hline Yield of wheat, $\mathrm{t} \cdot \mathrm{ha}^{-1}$ & 3.6 \\
\hline Plant density, $\mathrm{pcs} \cdot \mathrm{m}^{-2}$ & 496 \\
\hline Average plant height, $\mathrm{m}$ & 0.84 \\
\hline Weight of $1000 \mathrm{pcs}$. of seeds, $\mathrm{g}$ & 46 \\
\hline Ratio of the grain weight to the straw weight & $1: 1.6$ \\
\hline Losses of grain from self-shedding, \% & 0.2 \\
\hline Weediness of crops, $\mathrm{g} \cdot \mathrm{m}^{-2}$ & 42 \\
\hline
\end{tabular}

\section{Results and discussion}

As the results of the preliminary experimental investigations and tests of the trailed swath reapers show, during the harvesting period the soil moisture in the soil layer $0 \ldots 10 \mathrm{~cm}$ varies within the limits $10 \ldots .20 \%$. Hence it follows that, to ensure the desired stability of the movement of the trailed swath reaper, its design must provide that the supporting wheels are mounted in a horizontal plane at an angle of $0 \ldots 10^{\circ}$. The analysis of the obtained data showed that an increase in the speed of the working movement of the harvesting machine-and-tractor aggregate from 2.1 to $2.8 \mathrm{~m} \cdot \mathrm{s}^{-1}$ does not cause a growth in the height of the stubble of wheat. The difference between the average values of this indicator of $1.7 \mathrm{~cm}$ (Table 2) at a statistical significance level of 0.05 is random, since in this case $\mathrm{HIP}_{05}$ equals $2.1 \mathrm{~cm}$ (the smallest significant difference at the current level of significance 0.05) [13].

At the same time, with an increase in the speed of the movement up to $3.8 \mathrm{~m} \cdot \mathrm{s}^{-1}$, the average value of the height of the stubble of wheat increased to $23.6 \mathrm{~cm}$, which is significant and not random in contrast to the two previous modes of speed.

The same can be said about the mean square deviations of the estimated indicator. According to Fisher's F-criterion [13], the zero hypothesis of equality of the compared standards is rejected only when the harvesting machine-and-tractor aggregate is moving at a speed of $3.8 \mathrm{~m} \cdot \mathrm{s}^{-1}$.

As a result of the experimental field investigations, the value of the working width of the swath reaper was established, corresponding to the working speed of the forward movement of the asymmetrical trailed aggregate, at which efficient interaction of the operating tools of the reaper with the cut stalk density of cereals is achieved. Thus, to the speed of $1.8 \mathrm{~m} \cdot \mathrm{s}^{-1}$ corresponds a working width of the reaper of $6.08 \mathrm{~m}$, to $2.1 \mathrm{~m} \cdot \mathrm{s}^{-1}$ corresponds $5.92 \mathrm{~m}$, to $2.8 \mathrm{~m} \cdot \mathrm{s}^{-1}$ corresponds $5.88 \mathrm{~m}$, to 
$3.8 \mathrm{~m} \cdot \mathrm{s}^{-1}$ corresponds $5.8 \mathrm{~m}$. Based on the analysis of the experimental data, the function of the dependence of the working width of the trailed swath reaper $B$ on the speed of the harvesting aggregate $V$ has been established:

$$
B=0.0743 V^{2}-0.537 V+6.774 .
$$

Performance indicators of the trailed swath reaper

\begin{tabular}{|c|c|c|c|c|}
\hline \multirow{2}{*}{ Indicator } & \multicolumn{4}{|c|}{ Speed of the movement of the MTA, $\mathrm{m} \cdot \mathrm{s}^{-1}$} \\
\hline & 1.8 & 2.1 & 2.8 & 3.8 \\
\hline $\begin{array}{l}\text { Parameters of the swath reaper: } \\
\text { turn the left wheel, deg. } \\
\text { turn the right wheels, deg. }\end{array}$ & $\begin{array}{l}8 \\
8\end{array}$ & $\begin{array}{l}8 \\
8\end{array}$ & $\begin{array}{l}8 \\
8\end{array}$ & $\begin{array}{l}8 \\
8\end{array}$ \\
\hline $\begin{array}{l}\text { Stubble height: } \\
\text { average value, cm } \\
\left(\mathrm{HIP}_{05}=2.1 \mathrm{~cm}\right) \text { standard, } \pm \mathrm{cm} \\
\text { coefficient of variation, } \%\end{array}$ & $\begin{array}{c}17.8 \\
2.4 \\
11.9\end{array}$ & $\begin{array}{l}18.8 \\
2.4 \\
12.7\end{array}$ & $\begin{array}{c}20.5 \\
2.3 \\
11.2\end{array}$ & $\begin{array}{c}23.6 \\
5.8 \\
21.8\end{array}$ \\
\hline $\begin{array}{l}\text { Average value of the working width, } \mathrm{m} \\
\left(\mathrm{HIP}_{05}=0.10 \mathrm{~m}\right)\end{array}$ & 6.08 & 5.92 & 5.88 & 5.80 \\
\hline $\begin{array}{l}\text { Characteristics of the swath: } \\
\text { thickness cm } \\
\text { width, cm } \\
\text { distance to soil, }\end{array}$ & $\begin{array}{c}23.2 \\
177.4 \\
12\end{array}$ & $\begin{array}{c}23.6 \\
175.5 \\
12\end{array}$ & $\begin{array}{c}25,0 \\
154.8 \\
13\end{array}$ & $\begin{array}{c}27.6 \\
149.5 \\
14\end{array}$ \\
\hline Preferred angle of the stems, deg. & 66 & 65 & 56 & 58 \\
\hline $\begin{array}{l}\text { Losses behind the swath reaper: } \\
\text { total, } \% \\
\text { including the loose grain } \\
\text { grain from the cut ears } \\
\text { grain from not-cut ears }\end{array}$ & $\begin{array}{c}0.16 \\
0.10 \\
0.06 \\
0\end{array}$ & $\begin{array}{c}0.17 \\
0.10 \\
0.07 \\
0\end{array}$ & $\begin{array}{c}0.21 \\
0.11 \\
0.10 \\
0\end{array}$ & $\begin{array}{l}0.27 \\
0.10 \\
0.13 \\
0.04\end{array}$ \\
\hline
\end{tabular}

As a result of the conducted experimental investigations, the impact of the speed of the movement of the asymmetric harvesting aggregate $V$ upon the quality of the cut stalk density, determined by the average height of the stubble $H$ and the coefficient of variation of its value $V_{N}$, was established. Their graphical interpretation is shown in Fig. 4, Curve 1.

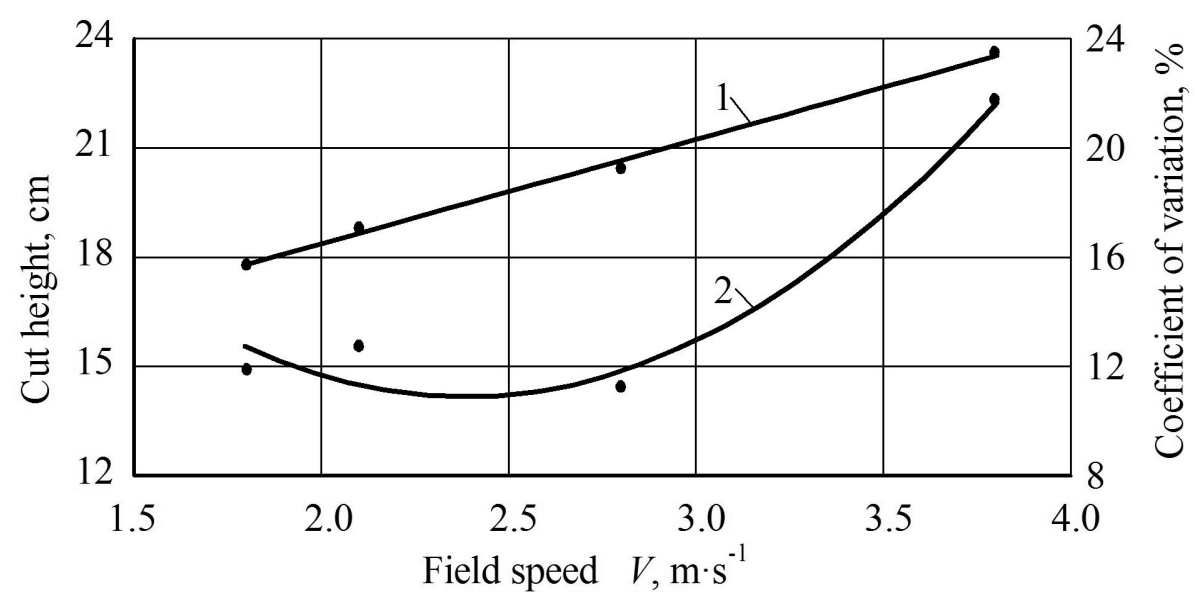

Fig. 4. Dependence of average value of height of stubble (1) and coefficient of variation of height of stubble (2) upon working speed of movement of asymmetric harvesting aggregate $(\sigma=1.20 \mathrm{~cm})$

It has been established that, with an increase in the speed of the movement of the aggregate, the height of the stubble will increase proportionally according to a linear dependence: from $17.8 \mathrm{~cm}$ at a speed of $1.8 \mathrm{~m} \cdot \mathrm{s}^{-1}$ to $23.6 \mathrm{~cm}$ at $3.8 \mathrm{~m} \cdot \mathrm{s}^{-1}$. This dependence is represented by a function that best approximates the experimental data of the form: 


$$
H=2.8564 V+12.677 \text {. }
$$

The increase in the value of the coefficient of variation of the height of the stubble $V_{N}$, when the working speed of the movement of the aggregate $V$ increases, is described by a function of a polynomial of the second degree of the following kind:

$$
V_{N}=5.2918 V^{2}-25.157 V+40.842,
$$

and the graph of this dependence has the form given in Fig. 4, Curve 2.

According to this dependence, the minimum value of the coefficient of variation of the cutting height, which determines the most uniform cut, is achieved at the forward speed of the harvesting aggregate equal to $2.38 \mathrm{~m} \cdot \mathrm{s}^{-1}$.

During the operation of the asymmetric swath reaper aggregate a swath is formed, the width and thickness of which, according to the research, is also affected by the working speed of the aggregate (Fig. 5).

Increasing the speed of the movement of the swath reaper, the width of the formed swath decreases (Fig. 3, Curve 1), but its thickness, on the contrary, increases (Fig. 5, Curve 2). Their value also depends on the working width of the swath reaper, which depends on the speed of its movement. Thus, at a speed of the reaper $1.8 \mathrm{~m} \cdot \mathrm{s}^{-1}$, which corresponds to the minimum speed during the experimental field investigations, the width of the swath is $177.4 \mathrm{~cm}$, and its thickness is $23.2 \mathrm{~cm}$. At a speed of the movement of the swath reaper of $3.8 \mathrm{~m} \cdot \mathrm{s}^{-1}$, the width and thickness of the swath are $149.5 \mathrm{~cm}$ and $27.6 \mathrm{~cm}$, respectively. In addition to it, at all speeds the asymmetrical reaper aggregate formed rectilinear swaths (Fig. 6).

The impact of the speed of the movement of the harvesting aggregate $V$ upon the width $B_{L}$ and the thickness of the roll $H_{L}$ is described by functions of such type:

$$
\begin{aligned}
& B_{L}=7.5581 V^{2}-57.717 \mathrm{~V}+259.25, \\
& H_{L}=0.4091 V^{2}-0.0791 \mathrm{~V}+21.996 .
\end{aligned}
$$

It has been substantiated that one of the main ways of efficient formation of a swath by a swath reaper, when harvesting cereals, is an ability to change the speed of the conveyor belts of the swathe reaper depending on the working speed of the harvesting aggregate. Since one of the most significant indicators of the quality of work during the cereal harvesting is the loss of grains behind the reaper, the impact of the speed of the movement of the harvester $V$ upon the total losses of the grains $P$ behind the reaper, as well as the losses of the loose grains $P_{1}$, the grains in the cut ear $P_{2}$ and the grains in the notcut ear $P_{3}$ were established. The graphs of dependences of the value of the total loss of cereals and their individual kinds are shown in Fig. 7.

According to the analysis of the obtained results, it was found that, increasing the forward speed of the movement of the swath reaper, the total losses of cereals also increase (Fig. 7, Curve 1).

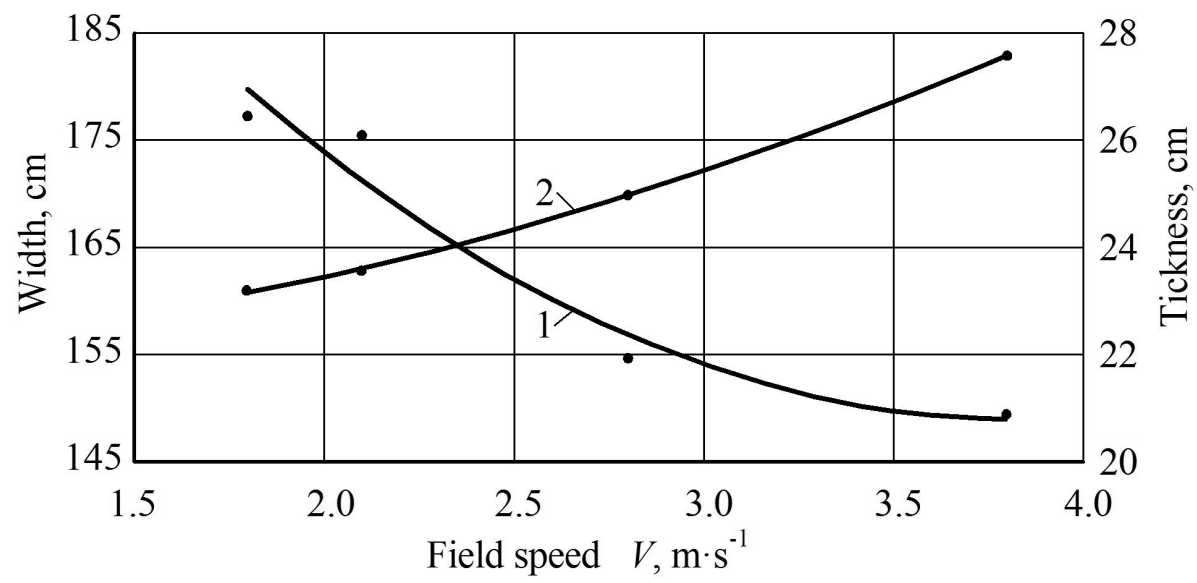

Fig. 5. Dependence of width (1) and thickness (2) of swath on working speed of reaper aggregate $(\sigma=3.80 \mathrm{~cm})$ 


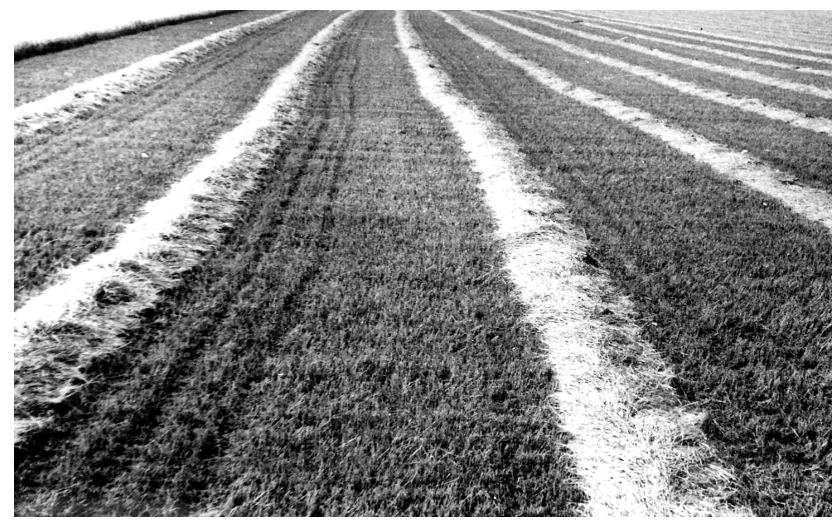

Fig. 6. View of swaths formed by swath reaper at speed of working movement of harvesting machine-and-tractor aggregate equal to $3.8 \mathrm{~m} \cdot \mathrm{s}^{-1}$

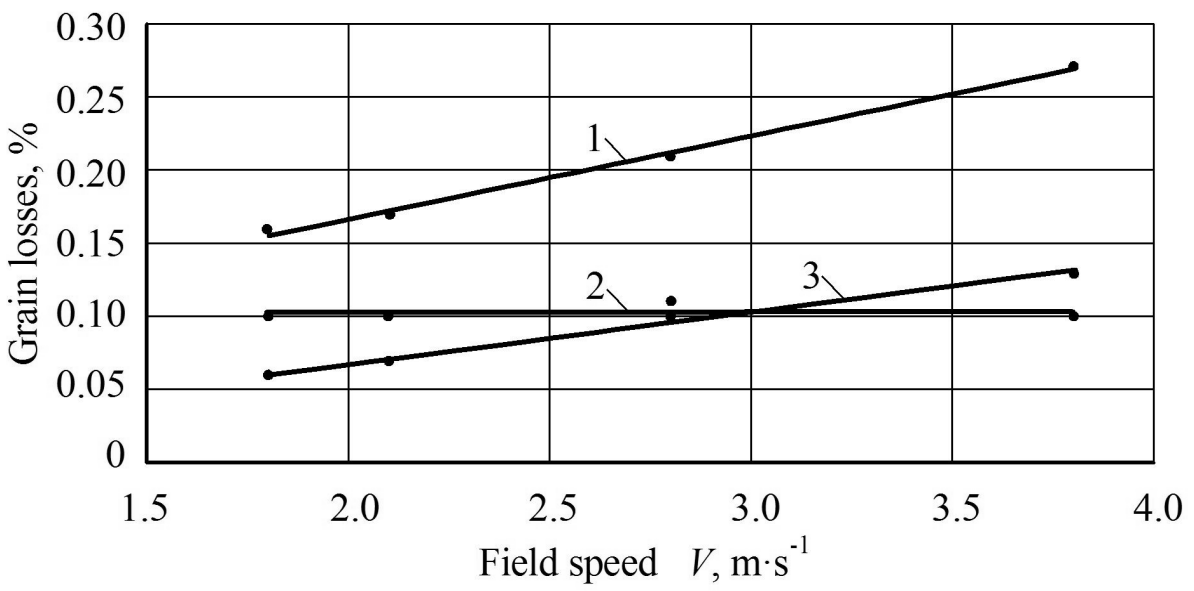

Fig. 7. Graph of dependence of total losses of cereals behind swath reaper (1), loose grains (2) and grains in cut ear (3), upon working speed of aggregate $(\sigma=0.008 \%)$

In addition to this, increasing the speed of the movement of the swath reaper, the losses of grains in the cut ear will also increase (Fig. 7, Curve 3), although the value of the losses of cereals has an almost constant value at different speeds of the header $-0.10 \ldots 0.11 \%$ (Fig. 7, Curve 2). The increase in the total losses of grain at the speed of the movement of the reaper $3.8 \mathrm{~m} \cdot \mathrm{s}^{-1}$ is explained by the losses of grain in the uncut ears $(0.04 \%)$, which did not appear at lower speeds. On the whole, the total losses of grain behind the trailed swath reaper at all speeds did not exceed the values that are set by the agrotechnical requirements.

The impact of the speed of the movement of the swath reaper upon the total loss of cereals is described by a functional dependence of the following kind:

$$
P=0.0056 V^{2}+0.0242 V+0.0966 \text {. }
$$

When using a more improved swath reaper, in contrast to the base variant, the productivity of the main time increases from $4.1 \mathrm{ha} \cdot \mathrm{h}^{-1}$ to $4.34 \mathrm{ha} \cdot \mathrm{h}^{-1}$, the specific fuel consumption - from $2.85 \mathrm{~kg} \cdot \mathrm{ha}^{-1}$ to $2.65 \mathrm{~kg} \cdot \mathrm{ha}^{-1}$, and the total loss of the loose grains and the grains in the cut ear - from $1.3 \%$ to $0.2 \%$, which confirms the expediency of the improvement.

The mean square deviations of the height of the wheat stubble in the first and the second highspeed modes represent the same random process, i.e. they are statistical characteristics of the same general totality. As regards the variability of the considered process (fluctuation in the height of the wheat stubble), when the harvesting machine-and-tractor aggregate is moving at a speed 2.1 and $2.8 \mathrm{~m} \cdot \mathrm{s}^{-1}$, then, judging by the values of the coefficients of variation, this variability is average, but at the speed of the movement $3.7 \mathrm{~m} \cdot \mathrm{s}^{-1}$ it is high (Table 2).

Analysis of the data in Table 2 shows that, with the increase in the speed of the movement of the harvesting aggregate, the width of the swaths decreases, but their thickness, on the contrary, increases. 
The obtained result is entirely logical, yet it points to the need to reequip the reaper so that its design is provided for a change in the speed of the conveyor belts depending on the change in the forward motion of this harvesting machine-and-tractor aggregate. The operational and technological tests of the experimental and the basic (a similar machine-and-tractor aggregate without a device for turning the supporting wheels of the trailed swath reaper) harvesting aggregates were carried out against the same agrotechnical background. The experimental harvesting machine-and-tractor aggregate moved at an average speed $7.36 \mathrm{~km} \cdot \mathrm{h}^{-1}\left(2.04 \mathrm{~m} \cdot \mathrm{s}^{-1}\right)$. The basic productivity of work was $4.27 \mathrm{ha} \cdot \mathrm{h}^{-1}$ (Table 3 ).

Table 3

Operational and technological indicators

of the swath reaper machine-and-tractor aggregates

\begin{tabular}{|c|c|c|}
\hline \multirow[t]{2}{*}{ Indicator } & \multicolumn{2}{|c|}{$\begin{array}{l}\text { Value for the machine- } \\
\text { and-tractor aggregates }\end{array}$} \\
\hline & new & basic \\
\hline $\begin{array}{l}\text { Conditions and mode of operation: } \\
\text { length of the furrow, } \mathrm{m} \\
\text { speed of the movement, } \mathrm{km} \cdot \mathrm{h}^{-1} \\
\text { working width, } \mathrm{m} \\
\text { height of the stubble, } \mathrm{cm} \\
\text { amount of the performed operation, ha }\end{array}$ & \multicolumn{2}{|c|}{$\begin{array}{c}1200 \\
7.367 .30 \\
5.905 .60 \\
15.016 .0 \\
60.057 .0\end{array}$} \\
\hline $\begin{array}{l}\text { Labour productivity per } 1 \text { hour: } \\
\text { basic time, ha } \\
\text { shift time, ha } \\
\text { operating time, ha } \\
\text { technological time, ha }\end{array}$ & $\begin{array}{l}4.34 \\
3.70 \\
3.60 \\
3.54\end{array}$ & $\begin{array}{l}4.10 \\
3.44 \\
3.30 \\
3.25\end{array}$ \\
\hline Specific consumption of fuel, $\mathrm{kg} \cdot \mathrm{ha}^{-1}$ & 2.65 & 2.85 \\
\hline $\begin{array}{l}\text { Agrotechnical indicators: grain losses behind the swath reaper } \\
\text { (loose grains and grains in the ear), } \%\end{array}$ & 0.20 & 1.30 \\
\hline
\end{tabular}

Nevertheless, taking into account the value of $\mathrm{HIP}_{05}$, which under the conditions of the experiment was $0.10 \mathrm{~m}$, this change is significant only in comparison of the first and the third modes of speed, i.e. it can be affirmed that by increasing the harvesting speed of the machine-and-tractor aggregate not less than by $67 \%$ (in this case, from 2.1 to $3.7 \mathrm{~m} \cdot \mathrm{s}^{-1}$ ), the working width of the swath reaper decreases (and it is no coincidence) by $2.0 \%$.

The basic harvesting machine-tractor aggregate moved at the same speed of the forward movement. But, due to a larger deviation of the swath reaper in a horizontal plane, its working width was by $5.1 \%$ less. As a result, the basic productivity of its work turned out to be by $5.5 \%$ and of the shift productivity - by $7 \%$ less. As the final result, this led to an increase in the specific fuel costs for the basic harvesting machine-and-tractor aggregate in comparison with the experimental one (see Table 3). The operational and technological indicators of the compared machine-and-tractor aggregates turned out to be approximately the same. As for such agrotechnical indicators, which are losses behind the swath reaper, the new aggregate has significantly (6.5 times) less losses. Higherquality work of the latter is ensured by practically absent deviation of a swath reaper, equipped with the devices for setting its supporting wheels at an angle to the direction of the movement (in this case, $\left.8^{\circ}\right)$. In case the supporting wheels of the trailed swath reaper are installed at an angle to the direction of its movement, there is practically no lagging during the right-side turn on the headland.

\section{Conclusions}

Better quality of the operation of an improved swath reaper is ensured by the devices for setting its supporting wheels at an angle of $8^{\circ}$ to the direction of its movement. When using a more improved swath reaper, in contrast to the base variant, the productivity of the main time increases from $4.1 \mathrm{ha} \cdot \mathrm{h}^{-1}$ to $4.34 \mathrm{ha} \cdot \mathrm{h}^{-1}$, the specific fuel consumption - from $2.85 \mathrm{~kg} \cdot \mathrm{ha}^{-1}$ to $2.65 \mathrm{~kg} \cdot \mathrm{ha}^{-1}$, and the total loss of the loose grains and the grains in the cut ear - from $1.3 \%$ to $0.2 \%$, which confirms the expediency of the improvement. 


\section{References}

[1] Rademacher T. Trends in the Process Technology of Grain Crop Harvesting. Agritechnica, No 6, 2003, pp. 362-368;

[2] Shinners K., Bennett R., Hoffman D. Single- and two-pass corn grain and stover harvesting. Transactions of the ASABE. Vol.55 (2), 2012, pp. 341-350;

[3] Bulgakov V., Pascuzzi S., Nadykto V., Ivanovs S. A mathematical model of the plane-parallel movement of an asymmetric machine-and-tractor aggregate. Agriculture, Vol. 8(10), 2018, 151.

[4] Гячев Л. Устойчивость движения сельскохозяйственных машин и агрегатов (Stability of the movement of agricultural machines and aggregates). Moscow, 1981, 206 p. (In Russian);

[5] Bulgakov V., Zaryshnyak A., Beloev H., Ivanovs S. Investigation of amplitude-frequency characteristics of disturbing and control impacts of asymmetric swath header machine-and-tractor aggregate. Engineering for rural development, proceedings, Vol. 17, 2018, pp. 221-226.

[6] Bevly D.M., Christian Gerdes J., Parkinson B.W. A new yaw dynamic model for improved high speed control of a farm tractor. Journal of Dynamic Systems, Measurement and Control, Transactions of the ASME, 124 (4), 2002, pp. 659-667;

[7] Löttjönen T., Mikkola H. Three mechanical weed control techniques in spring cereals Agricultural and Food Science in Finland. Volume 9, Issue 4, 2000, pp. 269-278;

[8] ГОСТ 20915-11. Техника сельскохозяйственная. Методы определения условий испытаний. (Agricultural machinery. Methods for the determination of the test conditions), Москва, 2011, 34 p.;

[9] ГОСТ 24055-2016. Техника сельскохозяйственная. Методы эксплуатационнотехнологической оценки (Agricultural machinery. Methods of operational and technological assessment), Москва, 2018, 24 p.;

[10] Smith D.W., Sims B.G., O'Neill D.H. Testing and evalution of agricultural machinery and equioment. FAO Agricultural services bulletin, No 110, 1994, 288 p.

[11] Bhatia, Nam Parshad; Szegö, Giorgio P. Stability theory of dynamical systems. Springer. 2002.

[12] Bulgakov V., Ivanovs S., Adamchuk V., Ihnatiev Y. Investigation of the influence of the parameters of the experimental spiral potato heap separator on the quality of work. Agronomy Research, Vol. 15(1), 2017, p. 44-54.

[13] Доспехов Б. Методика полевого опыта (Methodology of a field experiment). Москва, 2012, 352 p.;

[14] Spall J. C. Factorial Design for Efficient Experimentation: Generating Informative Data for System Identification. IEEE Control Systems Magazine, 30 (5), 2010, pp. 38-53. 